\title{
Empirical Use of Antibiotics in Adult Intensive Care Unit: a Real-Life Approach
}

\author{
Dragana D. Protić ${ }^{1}$, Maja M. Stojković ${ }^{1}$, Ljiljana N. Marković - Denić ${ }^{2,4}$, \\ Borislav Lj. Tošković ${ }^{3,4}$, Siniša F. Djuraševićs ${ }^{\prime}$ Marija D. Zdravkovićc, \\ Zoran M. Todorović ${ }^{1,4}$
}

${ }^{1}$ Department of Pharmacology, Clinical Pharmacology and Toxicology, School of Medicine, University of Belgrade, Belgrade, Serbia

${ }^{2}$ Department of Epidemiology, School of Medicine, University of Belgrade, Belgrade, Serbia ${ }^{3}$ School of Medicine, University of Belgrade, Belgrade, Serbia

${ }^{4}$ Clinical Center "Bezanijska kosa", Belgrade, Serbia

${ }^{5}$ Institute of Physiology and Biochemistry, Faculty of Biology, University of Belgrade, Belgrade, Serbia

\section{SUMMARY}

Introduction: Infection is the leading cause of complications in critically ill, and its presence significantly influences the treatment outcome. Empirical antibiotic therapy (EAT) is justified if limited to the time required for isolation and identification of pathogen, which is considered not to exceed 72 hours.

Aim: The aim of this study was to determine the rate of prolonged empirical antibiotic therapy (PEAT) in adult intensive care unit (ICU) - treated patients at the third level hospital and to assess factors influencing the antibiotic prescription practice in the hospital. The study also aimed to assess in-hospital mortality in patients treated with empirical antibiotic therapy (EAT) and to find parameters that were associated with fatal outcome. Subjects and Methods: Prospective observational study involved 51 consecutive patient who underwent EAT. Demographic, clinical and laboratory data were collected. The rate of PEAT was determined as the ratio of the total number of patients who received EAT longer than 72 hours divided by the total number of patients who received EAT regardless the length of its duration.

Results: The rate of PEAT was $80 \%$. In patients with diagnosed infection, length of EAT depended on the time needed for bacteria isolation. However, EAT was introduced and even prolonged in $33 \%$ of patients, in which infection was never confirmed. In-hospital mortality was $20 \%$, and factors associated with death outcome were ongoing sepsis and longer EAT. Conclusions: The practice of prescribing prolonged antibiotic therapy is very common in this study. This is associated with higher mortality, so it is necessary to find the cost-effective diagnostic method that helps in adjustment of rational empirical antibiotic treatment in ICU.

Keywords: empirical antibiotic therapy, intensive care unit, mortality, compliance guidelines 


\section{INTRODUCTION}

Infection is the leading cause of complications in critically ill, and its presence significantly influences the treatment outcome [1]. Clinical features (fever, fatigue, muscle aches) and biomarkers of bacterial infection (e.g. WBC, CRP, and PCT) are more or less specific and are often altered in critically ill $[2,3]$. Accordingly, diagnosis of infection relies mostly on positive microbiological cultures. Considering time-consuming conventional culture-based methods, empirical therapy is often the only option as delayed antibiotic therapy is associated with worse outcome [4,5]. Empirical antibiotic therapy (EAT) is justified if limited to the time required for isolation and identification of pathogen, which is considered not to exceed 72 hours [6-8] Any further use of antibiotics is considered prolonged. High incidence of a diagnostically challenging disease with significant mortality, leads to widespread use of antibiotics in intensive care unit (ICU) [9]. Moreover, antibiotics are initiated four times more than the infection is confirmed, and are frequently given longer than necessary $[6,10]$.

Current guidelines for treatment of infection are rigid and do not take interhospital differences and the local epidemiological situation into account. Therefore, treating patients in Europe according to the well-established American guidelines, and vice versa, is potentially inadequate. Moreover, there are differences among the guidelines for antibiotic therapy. Usually, a consensus should be reached among different specialists in ICU (e.g. anesthesiologists, clinical pharmacologists, and surgeons) regarding the most appropriate treatment of infections in critically ill.

\section{AIM}

The aim of this study was to determine the rate of prolonged empirical antibiotic therapy (PEAT) in adult ICU-treated patients at the third level hospital. In addition, we aimed at assessing factors influencing the antibiotic prescription practice in the hospital. Finally, the aim was to assess in-hospital mortality in patients treated with EAT and to find parameters that were associated with fatal outcome. Our study could be used as a model for similar health care establishments in developing countries.

\section{SUBJECTS AND METHODS}

Academic, prospective, observational study was performed at the Clinical Center "Bezanijska kosa" (BK), Belgrade, within the period from April $1^{\text {st }}$ to June $30^{\text {th }}, 2016$. The study was approved by the Ethics Committee of the BK (Ethical approval number 2722/4, from $7^{\text {th }}$ April 2016). Criteria for inclusion were: 1) hospitalization in ICU at BK during observed period, 2) course of empirical antibiotic therapy regardless indication. Patients receiving antibiotics for confirmed infection or surgical prophylaxis were excluded from the study. ICU has a total capacity of 14 beds. Demographic, clinical and laboratory data were collected.

The suspicion of infection was based on a clinical features (fever, fatigue, muscle aches) and biochemical markers of bacterial infection (WBC, CRP, and PCT). Before initiation of antibiotic treatment, microbiological samples were collected from patients. Definitive diagnosis was based on microbiological isolation and identification. The identification of isolated cultures of bacteria and susceptibility testing was performed by Vitek 2 system (bioMérieux, Mercy l'Etoile, France) according to the manufacturer's guidelines (Vitek 2 Compact S/N VK2C-2796 Systems Version: 07.01. Firmware BCB: 1.11; MIC Interpretation Guideline: CLSI+Phenotypic).

Empirical antibiotic therapy (EAT) was defined as the use of antibiotics in the treatment of a suspected infection, given prior to the identification of pathogen [11]. If EAT is continued over 72 hours without definitive diagnosis of infection it is considered prolonged [6]. Rate of prolonged empirical antibiotic therapy (PEAT) is determined as the ratio of the total number of patients who received empiric antibiotics longer than 72 hours divided by the total number of patients who received EAT regardless the length of her duration.

Criteria from the Sanford Guide to Antimicrobial Therapy [12] were used by two independent experts, clinical pharmacology specialists, to evaluate the appropriateness of EAT. Appropriate EAT implies that the route, dosage and choice of antibiotic was according guidelines for given indication.

Patients admitted to ICU for urgent surgery, as well as patients transferred from another medical ward due to clinical deterioration, were considered critically ill.

Clinical outcome was discharge sta- 
tus, i.e. death or hospital discharge.

Statistical analyses were performed using R, version 3.3.2. Data were analyzed by descriptive statistics (frequency, mean values \pm standard deviation, median and interquartile range of 25-75\%). Associations between potential risk factors and an outcome were tested using the parametric and nonparametric statistical tests (chi square test, Mann Whitney U-test, and Student's t-test), at the statistical significance level $p<0.05$. Logistic regression was not performed due to the small sample size versus the number of predictors', as the results of the test would not be reliable.

\section{RESULTS}

In total, we collected medical records of 51 consecutive ICU patients subjected to EAT during three-month period. Clinical and epidemiological data of patients treated with EAT are shown in Table 1.

The youngest patient was 21 , and the oldest was 87 years old (mean $68.43 \pm 13.09$ years). Median lengths of EAT and hospitalization were 6 days and 13 days, respectively.

Rate of PEAT was $80 \%$, i. e. empirical therapy was prolonged in $41 / 51$ patients.

Indicators of infection: biomarkers, clinical symptoms and microbiological confirmation were present in 51\% (26/51), 80\% $(41 / 51)$ and $67 \%(34 / 51)$ patients, respectively. In patients with definitive diagnosis of infection, median length of hospitalization ( $\mathrm{LoH})$ before isolation of bacteria was 5 days.

Appropriate EAT was initiated in $33 \%$ (17/51) patients.

Suspicion of sepsis was indication for initiating EAT in 22\% (11/51) patients. All patients treated for sepsis had microbiologically confirmed infection.

Most of the patients had one or more
Table 1. Clinical and epidemiological data of patients treated with empirical antibiotic therapy $($ EAT $)(N=51)$

${ }^{1} \mathrm{M}$ - median;

IQR $25-75 \%$ - interquartile range 25-75\%;

2 EAT - empirical antibiotic therapy;

* Only for patients with confirmed infection

\section{Parameter}

Age of patients (years)

Mean +/- SD

$68.43 \pm 13.09$

Range

21-87

Gender, N (\%)

Male

$32(62.75)$

Female

$19(37.25)$

Total length of hospitalization (days), M (IQR 25-75\%) ${ }^{1}$

$13(9-18)$

Length of EAT ${ }^{2}$ (days), M (IQR 25-75\%)

$6(4-8)$

Length of hospitalization before isolation of bacteria (days), M (IQR 25-75\%) ${ }^{1}$

$5(3.5-7.5)^{*}$

Infection indicators, N (\%)

Microbiological conformation

$34(66.7)$

Biomarkers of bacterial infection

$26(50.9)$

Clinical features

41 (80.4)

Appropriateness of EAT2 , N (\%)

\begin{tabular}{|l|c|}
\hline Appropriate & $17(33.3)$ \\
\hline Inappropriate & $34(66.7)$ \\
\hline Sepsis, N (\%) & $11(21.57)$ \\
\hline Suspected & $40(78.43)$ \\
\hline Not-suspected & \\
\hline The most significant comorbidities, N (\%) & $7(13.7)$ \\
\hline Cardiac arrhythmia & $35(68.6)$ \\
\hline Hypertension & $11(21.6)$ \\
\hline Diabetes mellitus & $21(35.0)$ \\
\hline Malignancy & \\
\hline Outcome, N (\%) & $41(80.4)$ \\
\hline Hospital discharge & $10(19.6)$ \\
\hline Death
\end{tabular}




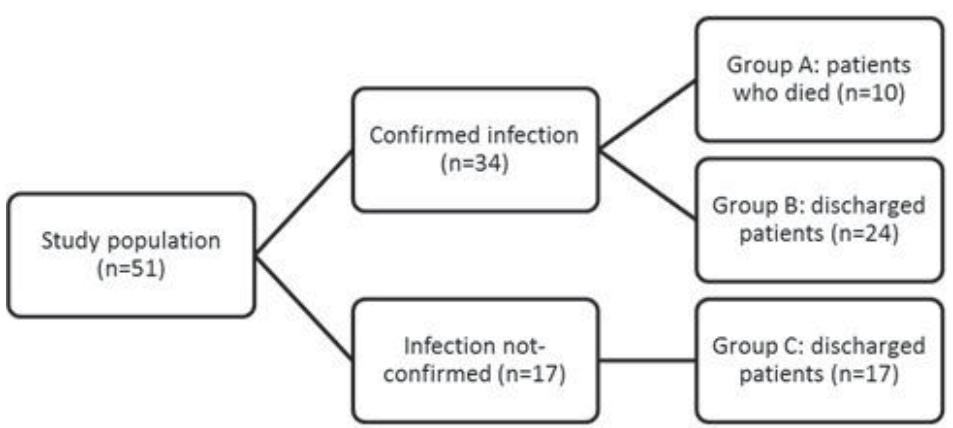

associated diseases that could lead to worse outcome. Common comorbidities were: arterial hypertension (65\%), malignancy (35\%) and diabetes mellitus (22\%).

Total study population was divided into three subgroups according to definitive identification of microorganisms and the clinical outcome (groups A, B and C, respectively, for details see Fig. 1).

Comparison of demographic and clinical characteristics of patients with confirmed infection (group $\mathrm{A}+\mathrm{B}$ ) with patients without confirmed infection (group C) showed no significant difference between groups, except in biomarkers of bacterial infection (WBC, CRP, and PCT), which were more frequently changed in patients with confirmed infection $(\chi 2, p<0.05)($ Table 2$)$.

Sepsis was indication for initiation of EAT only in patients with confirmed infection. No other differences were seen between these groups.

During the follow-up period, 10 out of 51 patients died, with calculated in-hospital mortality of $20 \%$ (Table 1). All fatal outcomes were recorded in group with proven infection, while all patients without microbiological confirmation were discharged from hospital.

In order to assess predictors of inhospital mortality, potential risk factors are compared only among patients with confirmed infection (Table 3 ).

There was no significant correlation between the age of patients and clinical outcome (Mann Whitney U-test, $\mathrm{p}>0.05$ ). Total LoH did not affect mortality (Mann-Whitney $\mathrm{U}$ test, $\mathrm{p}>0.05$, both). Based on results obtained from these two groups, strong positive linear correlation between length of EAT and LoH before isolation of bacteria was shown $(\mathrm{r}$ $=0.97, p<0.001$, Spearman's rank correlation coefficient). LoH before isolation of bacteria was significantly longer in patients who died ( $\mathrm{p}<0.05$, Mann-Whitney U test). Accordingly, length of EAT was significantly longer in patients in group $\mathrm{A}$ than in $\mathrm{B}(\mathrm{p}<0.05$, Mann-

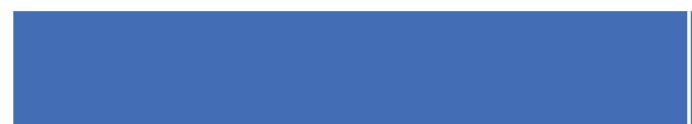

Age of patients (years), M (IQR 25-75\%) ${ }^{1}$

Length of EAT ${ }^{2}$ (days), M (IQR 25-75\%) ${ }^{1}$

Length of hospitalization (days), M (IQR 25-75\%) ${ }^{1}$

Biomarkers of bacterial infection, $\mathrm{N}(\%)$

Clinical features, $\mathbf{N}$ (\%)

Appropriate $\mathrm{EAT}^{2}, \mathrm{~N}(\%)$

Sepsis, N (\%)

Critically ill patients, $\mathrm{N}$ (\%)

The most significant comorbidities, N (\%)

Cardiac arrhythmia

Hypertension

Diabetes mellitus

Malignancy

\begin{tabular}{|c|c|}
\hline $\begin{array}{c}\text { Confirmed infection } \\
\text { Group A + Group B } \\
(\mathrm{N}=34)\end{array}$ & $\begin{array}{c}\text { Infection not } \\
\text { confirmed } \\
\text { Group C }(\mathrm{N}=17)\end{array}$ \\
\hline $68(63.75-83)$ & $64(54-74)$ \\
\hline $5.5(3.75-8)$ & $6(5-8)$ \\
\hline $14(9.75-19)$ & $10(8.5-16.5)$ \\
\hline $26(70.47) *$ & $5(29.41)$ \\
\hline $27(79.41)$ & $14(82.35)$ \\
\hline $13(38.24)$ & $5(29.41)$ \\
\hline $11(32.35) * *$ & $0(0.00)$ \\
\hline $26(70.47)$ & $11(64.71)$ \\
\hline $4(11.76)$ & \\
\hline $26(70.47)$ & $3(17.65)$ \\
\hline $9(26.47)$ & $9(52.94)$ \\
\hline $9(26.47)$ & $2(11.76)$ \\
\hline
\end{tabular}

Figure 1. Scheme of grouping patients based on outcome and microbiology confirmation of infection
Table 2. Clinical and epidemiological data of patients treated with empirical antibiotic therapy (EAT), grouped by microbiology confirmation of infection

${ }^{1} \mathrm{M}$ - median;

IQR $25-75 \%$ - interquartile range 25-75\%;

${ }^{2}$ EAT - empirical antibiotic therapy

${ }^{*} \mathrm{p}<0.05(\mathrm{x} 2)$

${ }^{* *} p<0.05$ (Fischer test) 
Table 3. Clinical and epidemiological data of patients treated with empirical antibiotic therapy (EAT), grouped by outcome

${ }^{1} \mathrm{M}$ - median;

IQR $25-75 \%$ - interquartile range 25-75\%;

${ }^{2}$ EAT - empirical antibiotic therapy

* $\mathrm{p}<0.05$ (Mann-Whitney $\mathrm{U}$ test)

${ }^{* *} p<0.05(x 2)$

\begin{tabular}{|c|c|c|}
\hline & \multicolumn{2}{|c|}{ Confirmed infection } \\
\hline & $\begin{array}{l}\text { Group A: Died } \\
\qquad(N=10)\end{array}$ & $\begin{array}{l}\text { Group B: Discharged } \\
(\mathrm{N}=24)\end{array}$ \\
\hline Age of patients (years), M (IQR 25-75\%) ${ }^{1}$ & $73.5(66.5-83)$ & $68(62.25-80.25)$ \\
\hline Length of EAT ${ }^{2}$ (days), M (IQR 25-75\%) ${ }^{1}$ & $7.5(5.5-11)^{*}$ & $5(3-7)$ \\
\hline Length of hospitalization (days), M (IQR 25-75\%) ${ }^{1}$ & $16(10.5-21)$ & $13(9-17)$ \\
\hline $\begin{array}{l}\text { Length of hospitalization before isolation of } \\
\text { bacteria (days), M (IQR 25-75\%) }\end{array}$ & $7.5(6-10.5)^{*}$ & $5(3-6.25)$ \\
\hline Biomarkers of bacterial infection, $\mathrm{N}(\%)$ & $10(100.0)$ & $16(66.67)$ \\
\hline Clinical features, N (\%) & $10(100.0)$ & $17(70.83)$ \\
\hline Appropriate EAT², N (\%) & $4(40.0)$ & $9(37.5)$ \\
\hline Sepsis, N (\%) & $7(70.0)^{* *}$ & $4(16.67)$ \\
\hline Critically ill patients, N (\%) & $9(90.0)$ & $17(70.83)$ \\
\hline \multicolumn{3}{|l|}{ The most significant comorbidities, $\mathrm{N}(\%)$} \\
\hline Cardiac arrhythmia & $3(30.0)$ & $2(8.33)$ \\
\hline Hypertension & $9(90.0)$ & $17(70.83)$ \\
\hline Diabetes mellitus & $4(40.0)$ & $5(20.83)$ \\
\hline Malignancy & $4(40.0)$ & $5(20.83)$ \\
\hline
\end{tabular}

Whitney U test).

Characteristic clinical symptoms and biomarkers of bacterial infection (WBC, CRP, and PCT) were recorded in both groups, but there was no significant difference between patients who survived, and those who did not ( $\chi 2, p>0.05$, both).

Appropriate EAT, defined as a use of antibiotic appropriate for the indication, did not affect the outcome $(\chi 2, p>0.05)$. But it is important to emphasize that the prescription of EAT was appropriate in less than a half of patients in both groups.

Sepsis was more often indication for initiation of EAT in Group A than in B $(\chi 2, p<$ $0.05)$, that is, sepsis was associated with mortality.

Presence of critical illness was not related to the more frequent occurrence of a particular outcome $(\chi 2, p>0.05)$. Similar results are obtained for the presence of individual comorbidity ( $\chi 2, p>0.05$, each separately).

\section{DISCUSSION}

Our study was conducted in the university medical center in Belgrade. To our knowledge, there are no published results about the empirical use of antibiotics in Serbia and the Region. In total, we collected medical records of 51 consecutive ICU patients subjected to EAT during three-month period.

According to European and Ameri- can guidelines, EAT is justified if introduced based on clinical presentation, experience of clinicians and local resistance patterns $[7,11]$. It should be limited to the time required for identification of pathogen and susceptibility testing. It is believed that seventy-two hours are an acceptable time frame for pathogen detection in conventional culture [6]. Any further use of antibiotics in the absence of confirmed infection is considered inappropriate and could lead to adverse clinical and microbiological outcomes (for example, increased mortality and spread of multidrug-resistant bacteria in clinical settings) [10]. Antibiotic use in our study was adjusted to these principles - length of the EAT was directly dependent on the LoH before isolation of the bacteria. However, time necessary for isolation was long, with median value of 6 days. Consequently, this resulted in a high rate of PEAT, which was $80 \%$ in the study. The main reason for the application of PEAT, in groups with confirmed infection (A and B), is extended time of hospitalization before isolation of bacteria. We cannot determine with certainty whether this is due to prolonged isolation time or failure of attending physician to provide adequate sample.

Of note, $33 \%$ of patients (17/51) without confirmed infection received EAT. There was no difference in length of EAT in this group compared to patients with confirmed infection. Similar observations were 
made in other studies conducted in the ICUs $[2,6]$. Even though previous studies showed that PEAT in patients without infection is not independently associated with mortality, this practice is unjustified and potentially harmful [10].

In present study, the only characteristics that distinguished patients with not-confirmed infection from those with confirmed infection were presence of biomarkers of the infection, which primarily refers to elevated PCT values. This finding is concordant with studies which suggest that PCT is most specific biomarker when determining presence or absence of bacterial infection [13-15]. In one-third of this study population, EAT was introduced based on the clinical symptoms and non-specific biomarkers of infection (WBC, CRP) which are frequently changed in critically ill. PCT is not routinely measured because the test is high-priced, significantly more than CRP and blood counts. However, recently conducted cost-effectiveness analysis showed that PCT guided antibiotic therapy leads to reduced number of patients receiving antibiotics, reduced antibiotic duration, reduced hospital and ICU stay, with no differences for adverse clinical outcomes [16]. Consequent reduction in the total cost was result of all reductions mentioned above. It is necessary to consider the routine use of the PCT as a marker that will more accurately, potentially without increasing costs, differentiate patients with infection from the ones without.

Another important measured outcome was in-hospital mortality, which reached $20 \%(10 / 51)$ in our study population. Examination of demographic and clinical characteristics according to our aims shows that there was no fatal outcome in a group without microbiological confirmation of infection. Therefore, assessment of potential mortality risk factors was made only among patients with confirmed infection. Two major observations were made: patients who died had significantly longer hospitalization before bacterial isolation and longer EAT than discharged patients. Although EAT was significantly longer in patients with fatal outcome than in group of patients who were discharged, empirical use of antibiotics in both groups was longer than recommended in current guidelines.

We further found that sepsis was an independent variable associated with increased mortality. Sepsis is one of the most common indications for the introduction of EAT in ICU, and also among the leading causes of death with a mortality rate of $27 \%$ to $54 \%$ [17]. Introduction of EAT within the first hour of sepsis onset is associated with increased survival to hospital discharge [18]. Antibiotics for treatment of sepsis were timely administered in the study. The basic principle of EAT involves changing broad-spectrum antimicrobial to a narrow-spectrum antimicrobial therapy, based on culture results [17]. Infection was microbiologically confirmed in all patients with sepsis, but as the EAT was prolonged, broad-spectrum antibiotics were longer used. No difference in mortality depending on the treatment (broad-spectrum or narrowspectrum antibiotics therapy) is proven [17]. Nevertheless, therapy should be switched to a narrow-spectrum antibiotic, since it allows an opportunity to limit overuse of broad-spectrum antibiotics, thereby reducing the costs and preventing resistance development.

Besides timely initiated EAT, appropriate EAT significantly reduces mortality in patients with sepsis, regardless the cause of the infection [19]. According to findings in this study, death outcome in patients receiving appropriate EAT was as frequent as in those receiving inappropriate EAT. According to Kariv et al., the pooled rate of inappropriate EAT is about $30 \%$, although the rates in individual studies were highly variable (calculated from 87 prospective studies with more than 27,000 patients) [20]. However, the frequency of inappropriate EAT in this study is very high, close to $70 \%$. Knowing local resistance map along with development of guidelines with the most appropriate empiric antibiotic treatment for each indication could possibly help in overcoming this problem. Medical students, medical doctors, specialists education specifically focused on prescription errors may contribute to improvement of antibiotic prescribing competence. The role of Hospitals clinical pharmacology units would be of clinical help [21, 22]. Limitation of the study is a small sample size. Therefore, false negative results could be expected and conclusions should be taken with reserve.

\section{CONCLUSION}

Despite the timely initiated EAT in our study, its duration was longer than recommended in current guidelines. Estimated rate of PEAT 
is $80 \%$, and prolongation of EAT in patients with confirmed infection directly depends on LoH before isolation of bacteria. Further, it is important to emphasize that in one-third of this study population, infection was never confirmed, but EAT was introduced and even prolonged. Elevated PCT values were only characteristic that distinguished patients with confirmed from those with not-confirmed infection.

In-hospital mortality was $20 \%$, and assessment of potential mortality risk factors showed that ongoing sepsis and longer EAT were associated with mortality.

It is necessary to evaluate the cost-effectiveness of methods with higher sensitivity and specificity to detect infection, in order to shorten the duration of empirical therapy and decrease the likelihood of prescribing PEAT in the absence of infection. This is a critical issue because the long-term and inadequate use of antibiotics is related with worse outcome.

\section{ACKNOWLEDGEMENTS}

This study was supported by the Scientific Research Grant from the Ministry of Education, Science and Technological Development of Serbia, No. OI 175046.

\section{CONFLICTS OF INTEREST}

All authors report no conflicts of interest relevant to this article.

\section{REFERENCES}

1. Anonymous. Communicable diseases. In: Ilic D (ed) Health Statistical Yearbook of Republic of Serbia 2015. Institute of Public Health of Serbia "Dr Milan Jovanovic Batut", Belgrade, Serbia; 2016. p. 398-418. Home page at: http://www.batut.org.rs/ download/publikacije/pub2015.pdf. [Accessed July 26, 2018]

2. Levin PD, Idrees S, Sprung CL, Weissman C, Weiss $\mathrm{Y}$, Moses AE, Benenson S. Antimicrobial use in the ICU: indications and accuracy-an observational trial. J Hosp Med 2012;7:672-8.

3. Pierrakos C, Vincent JL. Sepsis biomarkers: a review. Crit Care 2010;14:R15.

4. Bernhard M, Lichtenstern C, Eckmann C, Weigand MA. The early antibiotic therapy in septic patients - milestone or sticking point? Crit Care 2014;18:671

5. Weiss SL, Fitzgerald JC, Balamuth F, Alpern ER, Lavelle J, Chilutti M, Grundmeier R, Nadkarni VM, Thomas NJ. Delayed antimicrobial therapy increas- es mortality and organ dysfunction duration in pediatric sepsis. Crit Care Med 2014;42:2409-17.

6. Thomas Z, Bandali F, Sankaranarayanan J, Reardon T, Olsen KM. Critical Care Pharmacotherapy Trials Network. A multicenter evaluation of prolonged empiric antibiotic therapy in adult ICUs in the United States. Crit Care Med 2015;43: 2527-34.

7. Reddy P. Empiric antibiotic therapy of nosocomial bacterial infections. Am J Ther 2016;23:e982-94.

8. Leekha S, Terrell CL, Edson RS. General principles of antimicrobial therapy. Mayo Clin Proc 2011;86:156-67.

9. Aarts MW, Marshall JC. Empiric antibiotics in critical illness: Do they help or harm? In: Vincent $\mathrm{JL}$ (ed) Year-book of intensive care and emergency medicine. Springer, Berlin, Heidelberg, New York, 2003: 219-28.

10. Aarts MA, Brun-Buisson C, Cook DJ, Kumar A, Opal S, Rocker G, Smith T, Vincent JL, Smith T, Vincent JL, Marshall JC. Antibiotic management of suspected nosocomial ICU-acquired infection: does prolonged empiric therapy improve outcome? Intensive Care Med 2007;33:1369-78.

11. Fraser A, Paul M, Almanasreh N, Tacconelli E, Frank U, Cauda R, Borok S, Cohen M, Andreassen S, Nielsen AD, Leibovici L; TREAT Study Group. Benefit of appropriate empirical antibiotic treatment: thirty-day mortality and duration of hospital stay. Am J Med 2006;119:970-6.

12. The Sanford Guide to Antimicrobial Therapy (Android app.), 2019 edition. Antimicrobial Therapy, Inc. 2019.

13. Horie $M$, Ugajin $M$, Suzuki M, Noguchi S, Tanaka W, Yoshihara H, Kawakami M, Kichikawa Y, Sakamoto $Y$. Diagnostic and prognostic value of procalcitonin in community-acquired pneumonia. Am J Med Sci 2012;343:30-5.

14. Anand D, Das S, Bhargava S, Srivastava LM, Garg A, Tyagi N, Taneja S, Ray S. Procalcitonin as a rapid diagnostic biomarker to differentiate between culture-negative bacterial sepsis and systemic inflammatory response syndrome: a prospective, observational, cohort study. J Crit Care 2015;30:218 e7-12.

15. Cohn B. Can procalcitonin differentiate sepsis from systemic inflammatory response syndrome without infection? Ann Emerg Med 2014;63:631-2.

16. Westwood M, Ramaekers B, Whiting P, Tomini F, Joore M, Armstrong N, Ryder S, Stirk L, Severens $\mathrm{J}$, Kleijnen J. Procalcitonin testing to guide antibiotic therapy for the treatment of sepsis in intensive care settings and for suspected bacterial infection in emergency department settings: a systematic review and cost-effectiveness analysis. Health Technol Assess 2015;19:v-xxv, 1-236.

17. Silva BN, Andriolo RB, Atallah AN, Salomão $R$. De-escalation of antimicrobial treatment for adults with sepsis, severe sepsis or septic shock. 
Cochrane Database Syst Rev 2013;3:CD007934. doi: 10.1002/14651858.CD007934.pub3

18. Kumar A, Roberts D, Wood KE, Light B, Parrillo JE, Sharma S, Suppes $R$, Feinstein D, Zanotti S, Taiberg L, Gurka D, Kumar A, Cheang M. Duration of hypotension before initiation of effective antimicrobial therapy is the critical determinant of survival in human septic shock. Crit Care Med 2006;34:1589-96.

19. Paul M, Shani V, Muchtar E, Kariv G, Robenshtok E, Leibovici L. Systematic review and meta-analysis of the efficacy of appropriate empiric antibiotic therapy for sepsis. Antimicrob Agents Chemother 2010;54:4851-63.

20. Kariv G, Paul M, Shani V, Muchtar E, Leibovici L. Benchmarking inappropriate empirical antibiotic treatment. Clin Microbiol Infect 2013;19:629-33. doi: $10.1111 / j .1469-0691.2012 .03965 . x$

21. Petrov AD, Gatchev EM. Prescribing Assessment: Are Final Year Medical Students Competent to Prescribe Antibiotics Rationally? Hospital Pharmacology - International Multidisciplinary Journal 2018;5(3):673-679 (www.hophonline.org )

22. Kastratović DA, Djukić VB, Majstorović BM, Komrska JJ, Gajić MM, Marković SZ. Antibiotic consumption monitoring at the Institute of Otorhinolaryngology and Maxillofacial Surgery - Clinical Center of Serbia in 2001-2003. Vojnosanit Pregl 2005;62(78):551-555. 


\title{
Empirijska primena antibiotika u adultnoj jedinici intenzivnog lečenja: praktični pristup
}

\author{
Dragana D. Protić1, Maja M. Stojković ${ }^{1}$, Ljiljana N. Marković-Denićc,4, \\ Borislav Lj. Tošković, ${ }^{3,4}$, Siniša F. Djurašević, ${ }^{5}$, Marija D. Zdravković, ${ }^{3,4}$, \\ Zoran M. Todorović ${ }^{1,4}$ \\ ${ }^{1}$ Institut za farmakologiju, kliničku farmakologiju i toksikologiju, Medicinski fakultet, Univerzitet u Beo- \\ gradu, Beograd, Srbija \\ ${ }^{2}$ Institut za epidemiologiju, Medicinski fakultet, Univerzitet u Beogradu, Beograd, Srbija \\ ${ }^{3}$ Medicinski fakultet, Univerzitet u Beogradu, Beograd, Srbija \\ ${ }^{4}$ Kliničko bolnički centar "Bežanijska kosa”, Beograd, Srbija \\ ${ }^{5}$ Institut za fiziologiju i biohemiju, Biološki fakultet, Univerzitet u Beogradu, Beograd, Srbija
}

\section{KRATAK SADRŽAJ}

Uvod: Infekcija je vodeći uzrok komplikacija kod kritično obolelih i njeno prisustvo značajno utiče na ishod lečenja. Empirijska antibiotska terapija (EAT) je opravdana ako je ograničena na vrijeme potrebno za izolaciju i identifikaciju patogena, što podrazumeva da ne prelazi 72 sata.

Cilj: Odrediti stopu produžene empirijske antibiotske terapije (PEAT) u adultnoj jedinici intenzivnog lečenja (JIL) zdravstvene ustanove tercijarnog nivoa i proceniti faktore koji utiču na praksu propisivanja antibiotika u bolnici. Pored toga, izračunati mortalitet kod pacijenata lečenih empirijskom antibiotskom terapijom (EAT) i ispitati koji faktori dovode do nastanka fatalnog ishoda.

Metodologija: Prospektivna, akademska, opservaciona studija obuhvatila je 51 pacijenta podvrgnutog EAT. Prikupljani su demografski, klinički i laboratorijski podaci. Stopa PEAT je određivana kao odnos broja pacijenata koji su primili EAT duže od 72 sata i broja pacijenata koji su primali EAT bez obzira na dužinu primene.

Rezultati: Stopa PEAT iznosila je $80 \%$. Kod pacijenata sa mikrobiološki dokazanom infekcijom, dužina EAT zavisila je od vremena potrebnog za izolaciju bakterija. Međutim, EAT je uvedena, pa čak i produžena kod 33\% pacijenata, kod kojih infekcija nikada nije potvrđena. Bolnički mortalitet je bio $20 \%$, a faktori povezani sa fatalnim ishodom bili su sepsa i duža primena EAT.

Zaključak: Praksa propisivanja produžene antibiotske terapije je veoma česta u našoj studiji. Produžena primena antibiotika povezana je sa većom smrtnošću, pa je neophodno pronaći ekonomski isplativ dijagnostički metod koji će dovesti do racionalnije primene EAT u JIL.

Ključne reči: empirijska antibiotska terapija, jedinica intenzivnog lečenja, mortalitet, usklađenost sa vodičima 